\title{
Paleoproterozoic Greenstone-Granite Belts in Northern Brazil and the Former Guyana Shield - West African Craton Province
}

\author{
Ian McReath' (ianmcr@usp.br) and Maria Telma Lins Faraco² \\ 'Departamento de Mineralogia e Geotectônica - Instituto de Geociências - USP \\ R. do Lago 562, CEP 05508-080, São Paulo, SP, BRA \\ ${ }^{2}$ CPRM - Serviço Geológico do Brasil - Superintendência Regional de Belém, Belém, PA, BRA
}

Received 21 September 2005; accepted 22 February 2006

Keywords: paleoproterozoic greenstone-granite terrains; Guyana Shield; Northern Brazil; West African Craton.

\begin{abstract}
The mainly meta-volcano-sedimentary Vila Nova Group and associated granites constitute separate belts, which form part of a large paleoproterozoic (mainly rhyacian) province in the Guyana Shield of which northern Brazil forms a part, and the West African Craton. In Brazil the southwestern Serra do Ipitinga and Serra Tumucumaque-Serra do Navio belts have no obvious geometrical extensions in the Guyanas or Venezuela, and may represent deposits formed at penecontemporaneous passive continental margins and ocean floor spreading centres. To the Northeast the Serra Lombarda-Tartarugalzinho and Oiapoque belts are continuations of Guianese belts. In the former the igneous rocks have geochemical characteristics of suprasubduction environments. Belts in the Guyana Shield and West African Craton have many similar features. The megaprovince evolved in a number of stages, which may have started at about $2.3 \mathrm{Ga}$, and continued with diminished activity after $2.11 \mathrm{Ga}$. Both major juvenile additions and (possibly minor) reworking of earlier crust contributed to the growth of the province. The major transcurrent deformation, responsible for the present structure of the belts, probably occurred during the later stages of evolution of the province, but metamorphism and deformation are registered even in the oldest rocks.
\end{abstract}

Palavras-chave: terrenos paleoproterozóicos de greenstones e granitos; Escudo das Guianas; Norte brasileiro; Craton Oeste-Africano.

\section{RESUMO}

O Grupo Vila Nova, predominantemente meta-vulcanossedimentar e os granitos associados constituem cinturões que formam parte de uma grande província paleoproterozóica (predominantemente riaciana) localizada no Escudo Guianense do qual o Norte brasileiro faz parte, e no Craton Oeste-Africano. No Brasil identificam-se ambientes tectônicos diferenciados para os diferentes cinturões. No sudoeste da província os cinturões da Serra de Ipitinga, e da Serra de Tumucumaque ao Serra do Navio não encontram extensões geometricamente claras nas Guianas e Venezuela, e talvez representem depósitos penecontemporâneos formados em margens continentais passivas e bacias oceânicas. Seguindo para nordeste, os cinturões da Serra Lombarda até Tartarugalzinho e Oiapoque são continuações de cinturões presentes nas Guianas. Naquele, as características geoquímicas, tanto das rochas máficas metavulcânicas como das félsicas plutônicas posteriores, apontam para origens em zonas de supra-subducção. Os cinturões guianenses e oeste-africanos apresentam muitas feições e características semelhantes. A evolução da megaprovíncia ocorreu por etapas, desde talvez 2,3 Ga com atividade em diminuição depois de 2,11 Ga. Adições crustais, tanto juvenis quanto por retrabalhamento de crosta antiga, contribuíram para o crescimento da megaprovíncia. É provável que a deformação maior de transcorrência, responsável pela estrutura atual dos cinturões, ocorresse em fase tardia da evolução, embora mesmo as unidades mais antigas sejam deformadas e metamorfizadas. 


\section{INTRODUCTION}

Rocks which form part of the northern Brazilian paleoproterozoic greenstone-granite belts were first described from the Serra do Navio area in Amapá State by Paiva (1946). Since then, a number of regional mapping projects, whose attention was mainly directed towards the meta-volcano-sedimentary rocks were undertaken, and they demonstrated the widespread occurrence of similar associations throughout northwestern Pará and Amapá States. Many terms were introduced to designate the rocks but more recent compilations use the term Vila Nova Group, and divide it into informal rock units according to their origin and composition (Carvalho et al., 1995).

Detailed integrated studies have been published only for small areas scattered over the very large area of occurrence of the Vila Nova Group and associated granites, but are sufficient to point out major similarities and differences between the areas. At the same time, studies of related rocks in Venezuela and the Guyanas, and in West Africa have advanced significantly, stimulated by the great economic potential of the former megaprovince, and it is now possible to review some of its main features. In this article we summarize available information on the main belts exposed in Brazil, pointing out the main similarities to, and differences from belts in the Guyana Shield and West African Craton. We attempt a paleotectonic reconstruction.

\section{THE VILA NOVA GROUP AND ASSOCIATED GRANITES}

The greenstone-granite terrains occur in an area of about 300 x $500 \mathrm{~km}$. Four main and other minor belts up to about $300 \mathrm{~km}$ long, from around 50 to about $120 \mathrm{~km}$ wide, oriented roughly NW-SE are separated by $120-150 \mathrm{~km}$ of basement rocks (Figure 1). The major belts discussed here are here named after prominent physiographic features. From southwest to northeast, we have the Serra do Ipitinga (abbreviated to Itipinga), Serra Tumucumaque-Serra do Navio (Tumucumaque-Navio), Serra Lombarda-Tartarugalzinho (Lombarda-Tartarugalzinho) and Oiapoque belts. Isolated occurrences on the Cupixi River and in the Igarapé do Breu may be outliers of the Tumucumaque-Navio belt.

\section{Basement rocks}

Archaean TTG gneiss-migmatites of the Guianense Complex (Montalvão and Tassinari, 1984; Sato and Tassinari, 1997; Avelar, Lafon, Delor, 2001; Avelar et al., 2003; RosaCosta et al., 2003), and late archaean to early paleoproterozoic granulites of the Jari and Tartarugal belts (Scarpelli, 1966; Lima et al., 1982; Montalvão and Tassinari, 1984; Avelar et al., 2003) are the main basement rocks. Crust is thinner under the southwestern Maecuru block, which was thrust northeastwards over the thicker Oiapoque block with the NW-SE oriented suture situated just northeast of the Serra do Ipitinga belt (Hasui, Haraly, Schobbenhaus, 1984).

Deformed metamafic-ultramafic rocks have been identified in the Navio sector (Mattos, Spier, Soares, 1992; Spier and Ferreira Filho, 2001; Horikava and Ferreira Filho, 2003) and in the Ipitinga belt (Faraco et al., 2004). In the former sector the Bacuri complex (Figure 1: $\mathrm{U}_{\mathrm{b}}$ ) hosts important chromite deposits with continental stratiform affinities (Matos, Spier, Soares, 1992; Coelho Filho in Soier and Ferreira Filho, 1999; Spier and Ferreira Filho, 1999, 2001; Prichard, Sá, Fisher, 2001). Sm-Nd studies (Pimentel, Ferreira Filho, Spier, 2002) suggest that the complex was intruded into continental crust at about the same time (ca. 2.1 $2.2 \mathrm{Ga}$ ) that volcanism in other tectonic environments was occurring in, for example, the Ipitinga sector. Horikava and Ferreira Filho (2003) consider that the Canga and Bicicleta occurrences which they studied are sills injected into the meta-volcano-sedimentary sequence, and should be considered as part of the Vila Nova Group.

The basal conglomerate of the Vila Nova Group overlying the Bacuri complex contains pebbles derived from it. The complex in the Ipitinga belt is cut by undated undifferentiated granites, and by the $2.14 \mathrm{Ga}$ Carecuru intrusive suite, and has therefore been correlated with the Bacuri complex (Faraco et al., 2004). If this attribution is correct it has very important implications for the tectonic situation in this belt.

\section{The Vila Nova Group and intrusive granites}

The mainly meta-volcano-sedimentary Vile Nova Group is composed of a number of lithological units:

1. undifferentiated intercalated metavolcanic and metasedimentary rocks;

2. amphibolite and mafic/ultramafic schist;

3. mafic/ultramafic metaplutonic rocks;

4. quartzite, schist, gneiss and amphibolite in what was formerly known as the Serra Lombarda Group (Veiga, Brait Filho, Oliveira, 1985; Ferran, 1988), and which occur as inclusions in granitoid intrusions (Nogueira, Bettencourt, Tassinari, 2000);

5. schists and metavolcanic rocks which occur in the Tartarugalzinho area (Jorge João et al., 1978);

6. metaconglomerate;

7. conglomeratic quartzite;

8. quartzite;

9. banded iron formation; 


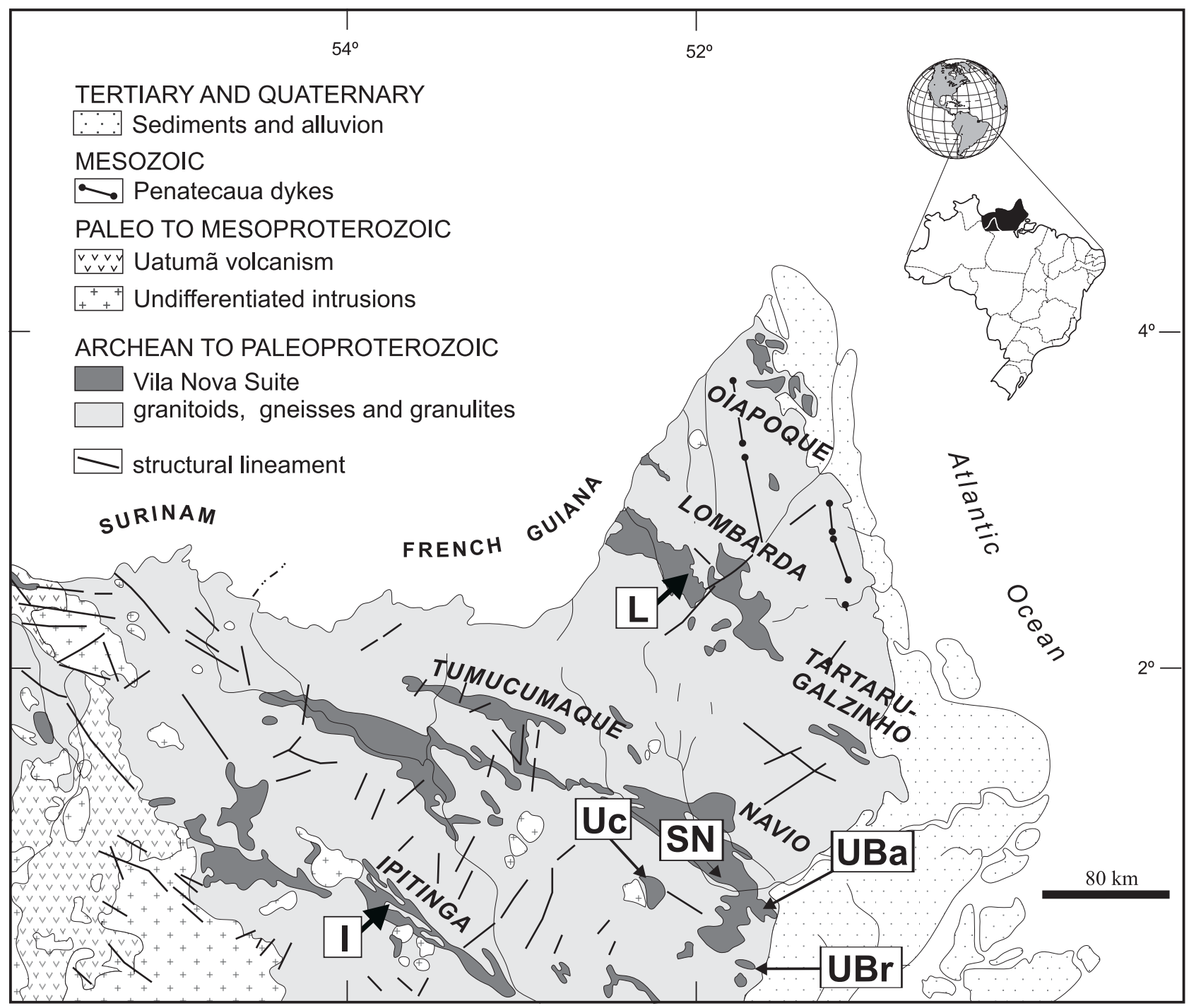

Figure 1. The Vila Nova Group and associated granites in Northern Brazil. Only a few of the granite intrusions can be individualized at this scale. $I$ and $L$ indicate the areas of detailed studies in the Ipitinga and Lombarda belts, respectively. The locations of the metamafic/ultramafic complexes of Cupixi (Uc), Bacuri (UBa) and Igarapé do Breu (UBr), and the Serra do Navio mine (SN) are indicated. Adapted from Carvalho, Faraco and Klein (1995) and Faraco, Marinho and Vale (2000).

10. banded manganese formation;

11. marble;

12. undifferentiated metasediments.

This subdivision is based on Carvalho, Faraco and Klein (1995) and Coelho Filho et al. in Spier and Ferreira Filho (1999), apart from references already cited. Special features of each of the major belts and the associated granitoids are as follows (Figure 2).

The Ipitinga belt overall has basal amphibolite, mafic schist, banded iron formation and quartzite. Strips of rock about $15 \mathrm{~km}$ wide mainly composed of islands of iron formation and continental sediments are surrounded by metavolcanic rocks including amphibolite. Granite-gneiss enclaves are present, and the sequence is cut by tonalitetrondhjemite-granodiorite and syenogranite intrusions (Jorge João et al., 1978; Carvalho, 1984).

A detailed section of the Vila Nova Group with a total width between about 1.5 and $2.5 \mathrm{~km}$ was described by Faraco (1990, 1997). It overlies high-grade basement rocks and includes basal amphibolite, intercalated mafic and ultramafic schists, metamafic breccia, banded rocks rich in quartz, 
(A)

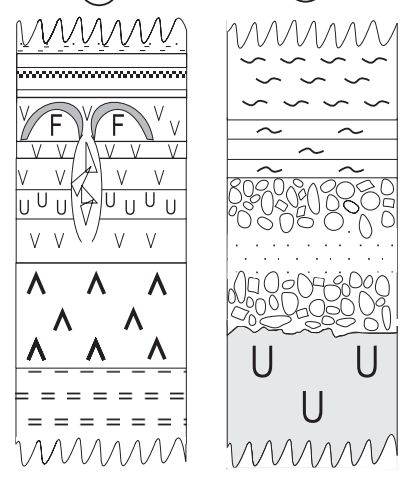

(C)

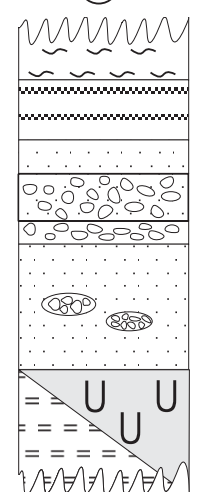

(D)

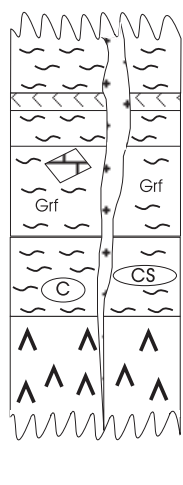

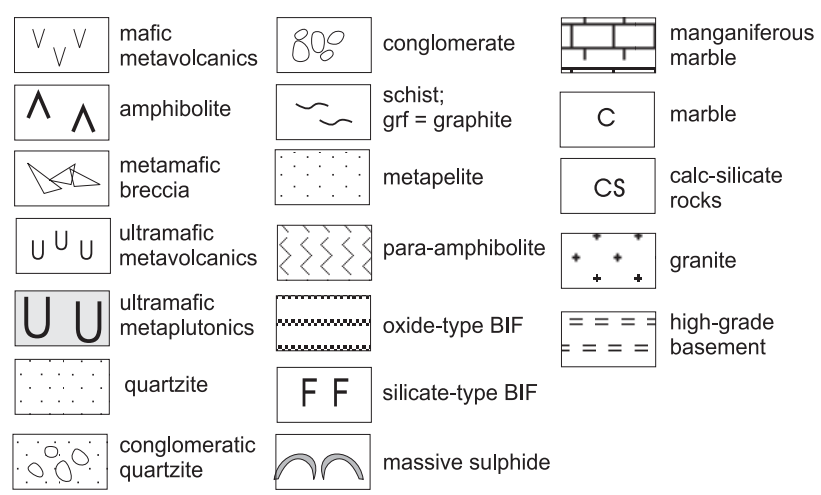

Figure 2. Schematic sections of the Vila Nova Group. No scale is implied, and some dimensions are given in the text. A. The Ipitinga belt in the detailed study area, after Faraco (1990, 1997). B. The Tumucumaque-Navio belt in the region of the Bacuri metamafic/ultramafic complex, adapted from Spier and Ferreira Filho (1999). C.The Tumucumaque-Navio belt over the Bacuri mafic/ultramafic complex. D. The Tumucumaque-Navio belt along the Vila Nova $30 \mathrm{~km} \mathrm{~N}$ of B. C and D adapted from Ferran (1988), Carvalho, Faraco and Klein (1995) and Coelho in Spier and Ferreira Filho (1999).

chlorite, anthophyllite and cordierite (BQCAC), and banded iron formation (BIF) of oxide, silicate and tourmaline type (Figure 2a). Some metamorphic features, such as the formation of quartz-chlorite rocks, were associated with seafloor metamorphism. The first regional metamorphism occurred under amphibolite facies conditions at about $5 \mathrm{~kb}$, while later retrograde metamorphism was associated with regional shearing. The principal metamorphic foliation is steeply dipping, and outcrop widths therefore approximately correspond to unit thicknesses. Overall shortening estimated from folded quartz veins was around $50 \%$.

The metamafic rocks are tholeiitic of uncertain tectonic situation (Table 1, numbers 2, 3 and 4). Low $\mathrm{TiO}_{2}, \mathrm{Na}_{2} \mathrm{O}$ and $\mathrm{Zr}$ contents are typical of modern immature island arc tholeiites (IOT), but are also found in refractory mid-ocean ridge basalts (MORB). The slight light rare earth element (LREE) enrichment found in most amphibolites is typical of modern transitional (T-MORB) or enriched (E-MORB) ocean floor basalts, but is also found in IOT. The same enrichment might be generated by high-pressure fractionation of $\mathrm{N}-\mathrm{MORB}$ magma involving garnet. Multi-element diagrams normalized to N-MORB for amphibolites with no more than traces of lower-grade minerals are spiky, probably due to mobilizations of elements during metamorphism, but are practically flat (Figure 4), and have no marked large ion lithophile element (LILE) enrichments nor $\mathrm{Nb}$ deficiencies which are common in modern supra-subduction magmas.

The ultramafic schists (Table 1, number 1) are probably basaltic komatiites. Their flat to slightly LREE enriched patterns may be secondary, but could also arise from highpressure fractionation involving garnet. The oxide type BIF forms $150-250 \mathrm{~m}$ wide lenses, $2-5 \mathrm{~km}$ long, while the silicatetype BIF (Table 1, number 5) are probably metamorphosed iron-rich clays. The oxide-type BIF has geochemical characteristics in common with many proterozoic examples (Faraco, McReath, Costa, 1992). A massive sulphide deposit with $\mathrm{Cu}-\mathrm{Au}-\mathrm{Ag}$ mineralization is associated with BQCAC, and a sulphide body revealed by conductivimetry also occurs at depth at the contact between mafic volcanics and oxidetype BIF. Together with the predominance of mafic rocks and the metamorphic already mentioned, the presence of the mineralization and probable volcano-exhalative deposits seems to leave no doubt that the Ipitinga rocks were formed at an oceanic spreading centre. Mineralizing fluids include reduced $\mathrm{CH}_{4}-\mathrm{N}_{2}$ and saline types (Faraco et al., 1995).

McReath and Faraco (1996) obtained an imprecise whole rock $\mathrm{Sm}-\mathrm{Nd}$ isochron age of about $2.26 \mathrm{Ga}$ for a mixed population of metamafic and metaultramafic rocks. A4-point isochron for mafic rocks having mainly minerals formed during the regional metamorphism, with only minor inheritance from the sea floor metamorphism and no obvious retrograde overprinting, yielded an age of $2.27 \pm 0.07(2 \sigma) \mathrm{Ga}$ (MSWD =0.49; Table 2, Figure 3). Plausible $\mathrm{T}_{\mathrm{DM}}$ model ages in the range $2.1-2.3 \mathrm{Ga}$ are obtained for many of the analysed samples, suggesting that the isochron age represents the age of extraction from the mantle, while most $\varepsilon_{\mathrm{Nd}}(2.3 \mathrm{Ga})$ values are in the range $+2-+6$, compatible with theoretical time-dependent isotopic evolution of depleted mantle.

The associated granitoids include (Faraco, 1990, 1997) mylonitic two-mica-bearing syenogranite; slightly foliated, intensely altered hornblende granodiorite; slightly foliated to mylonitic, porphyritic biotite-bearing alkali-feldspar granite with subhedral accessory allanite surrounded by epidote; and isotropic alkali-feldspar granite with accessory biotite and opaque Fe-Ti minerals. The majority of these types with alkali-calcic to alkalic affinities (Figure 5) are typical of syn- to 
Table 1. Selected analyses of rocks of the Vila Nova Group and associated granitoids. Details of samples:

1 - 6 from detailed study area, Ipitinga belt, from Faraco $(1990,1997)$; analyses by standard classical and instrumental methods of LAMIN-CPRM except REE, ICP by GEOSOL; 7, this work, analyses mostly by X-ray fluorescence spectrometry on fused disc (majors) and pressed powder disc (traces) with calibration using international standards: 1) S-232 actinolite schist; 2) S-4 typical less differentiated amphibolite on basis of $\left.\mathrm{MgO} /\left(\mathrm{MgO}+\mathrm{FeO}_{t}\right) ; 3\right) \mathrm{S}-88$ differentiated amphibolite with K-metasomatism; 4) S-22 metadiabase; 5) S-294 silicate-type banded iron formation; 6) S-412 hydrothermally-altered mylonitic biotite syenogranite with magmatic allanite, epidote and titanite; 7) 1717R194W tonalite.

8 - 10 from Serra do Navio segment, Tumucumaque-Navio belt; this study: 8) CA-17, granodiorite; 9) TF-04c, syenogranite; 10) TF-05b2, tonalite, Serra do Navio.

11 - 12 Tartarugalzinho and adjacencies; this study: 11) TF-14 monzogranite; 12) TF-28A granodiorite; 13) 1004VBR379 high-Ti tholeiitic amphibolite; 14) 1004VBR378 monzogranite.

(a) loss on ignition; (b) totals rounded to one significant figure; nd - not detected.

\begin{tabular}{|c|c|c|c|c|c|c|c|c|c|c|c|c|c|c|}
\hline & 1 & 2 & 3 & 4 & 5 & 6 & 7 & 8 & 9 & 10 & 11 & 12 & 13 & 14 \\
\hline $\mathrm{SiO}_{2}$ & 46.2 & 51.7 & 49.6 & 50.1 & 54.8 & 72.4 & 71.0 & 73.3 & 73.8 & 62.5 & 69.2 & 64.6 & 47.6 & 71.1 \\
\hline $\mathrm{TiO}_{2}$ & 0.52 & 1.1 & 1.0 & 0.83 & 0.42 & 0.29 & 0.27 & 0.20 & 0.01 & 0.69 & 0.31 & 0.23 & 2.73 & 0.22 \\
\hline $\mathrm{Al}_{2} \mathrm{O}_{3}$ & 4.7 & 13.2 & 14.2 & 14.2 & 12.3 & 13.2 & 16.5 & 14.8 & 14.3 & 15.6 & 14.6 & 18.5 & 13.7 & 15.2 \\
\hline $\mathrm{Fe}_{2} \mathrm{O}_{3}$ & 1.9 & 3.9 & 5.2 & 7.4 & 2.8 & 2.7 & 0.42 & 0.30 & 0.12 & 1.27 & 0.55 & 0.47 & 3.24 & 0.38 \\
\hline $\mathrm{FeO}$ & 8.2 & 9.5 & 9.1 & 6.3 & 22.9 & 0.17 & 1.50 & 1.07 & 0.43 & 4.58 & 1.97 & 1.68 & 11.7 & 1.35 \\
\hline $\mathrm{MnO}$ & 0.19 & 0.16 & 0.26 & 0.13 & 0.26 & 0.04 & 0.03 & 0.04 & 0.11 & 0.13 & 0.05 & 0.03 & 0.21 & 0.04 \\
\hline $\mathrm{MgO}$ & 14.0 & 9.8 & 5.3 & 6.2 & 2.0 & 0.17 & 0.74 & 0.41 & 0.02 & 2.90 & 1.36 & 0.20 & 5.62 & 0.59 \\
\hline $\mathrm{CaO}$ & 17.7 & 7.0 & 10.4 & 10.7 & 2.3 & 0.70 & 2.67 & 1.26 & 0.44 & 5.07 & 2.42 & 0.87 & 10.2 & 1.90 \\
\hline $\mathrm{Na}_{2} \mathrm{O}$ & 0.22 & 2.2 & 1.8 & 2.4 & 0.04 & 3.0 & 4.67 & 4.99 & 3.60 & 3.84 & 3.47 & 7.33 & 2.30 & 4.41 \\
\hline $\mathrm{K}_{2} \mathrm{O}$ & 0.08 & 0.05 & 0.97 & 0.07 & 0.05 & 6.1 & 1.63 & 2.91 & 6.51 & 2.05 & 4.70 & 4.83 & 0.35 & 3.32 \\
\hline $\mathrm{P}_{2} \mathrm{O}_{5}$ & 0.05 & 0.11 & 0.11 & 0.10 & 0.15 & 0.05 & 0.05 & 0.07 & 0.04 & 0.17 & 0.12 & 0.06 & 0.19 & 0.07 \\
\hline $\mathrm{H}_{2} \mathrm{O}^{+}$ & $5.7^{(\mathrm{a})}$ & 0.92 & 0.96 & 0.82 & - & 0.2 & - & - & - & - & - & - & - & - \\
\hline $\mathrm{H}_{2} \mathrm{O}^{-}$ & - & 0.22 & 0.25 & 0.37 & - & - & - & - & - & - & - & - & - & - \\
\hline $\mathrm{CO}_{2}$ & - & 0.06 & 0.06 & 0.04 & - & - & - & - & - & - & - & - & - & - \\
\hline$S$ & - & 0.05 & 0.13 & 0.38 & - & - & - & - & - & - & - & - & - & - \\
\hline Total $^{(\mathrm{b})}$ & 99.8 & 101.1 & 100.8 & 101.4 & 98.3 & 99.02 & 99.4 & 99.3 & 99.4 & 98.8 & 98.7 & 98.8 & 97.8 & 98.6 \\
\hline Co & 70 & 55 & 65 & 45 & 20 & 2.5 & 3 & 2 & 2 & 15 & 5 & 2 & 43 & 3 \\
\hline $\mathrm{Ni}$ & 640 & 150 & 140 & 155 & 55 & 15 & 3 & 2 & 1 & 18 & 13 & 3 & 76 & 5 \\
\hline Sc & - & - & - & - & - & - & 2 & 2 & 2 & 16 & 37 & 2 & 16 & 2 \\
\hline $\mathrm{Rb}$ & nd & nd & 42 & nd & nd & $<10$ & 82 & 179 & 181 & 91 & 117 & 178 & 11 & 107 \\
\hline $\mathrm{Sr}$ & 10 & 72 & 60 & 74 & nd & $<10$ & 325 & 234 & 50 & 447 & 494 & 466 & 222 & 466 \\
\hline $\mathrm{Ba}$ & - & 115 & 70 & 115 & - & 700 & 366 & 682 & 45 & 453 & 1239 & 1048 & 24 & 1048 \\
\hline$Y$ & nd & 38 & 13 & 38 & 16 & 46 & 8 & 7 & 24 & 22 & 12 & 131 & 31 & 16 \\
\hline $\mathrm{Zr}$ & 58 & 87 & 62 & 56 & 107 & 272 & 151 & 136 & 33 & 187 & 155 & 194 & 131 & 106 \\
\hline $\mathrm{Nb}$ & nd & 10 & 6 & 8 & nd & 18 & 8 & 7 & nd & 10 & 6 & 15 & 11 & 6 \\
\hline Th & - & - & - & - & - & - & 8 & 11 & 1.5 & 3 & 12 & 74 & 1.5 & 5 \\
\hline La & 3.17 & 6.99 & 5.75 & 4.58 & 19.41 & - & 33 & 26 & 7 & 23 & 57 & 186 & 13 & 16 \\
\hline $\mathrm{Ce}$ & 7.69 & 18.64 & 14.94 & 13.37 & 36.43 & - & 49 & 60 & 18 & 57 & 100 & 246 & 27 & 58 \\
\hline $\mathrm{Nd}$ & 5.4 & 11.05 & 9.55 & 8.24 & 19.12 & - & 27 & 23 & 11 & 28 & 67 & 133 & 11 & 11 \\
\hline Sm & 1.61 & 3.32 & 3.07 & 2.59 & 4.14 & - & - & - & - & - & - & - & - & - \\
\hline $\mathrm{Eu}$ & 0.65 & 0.95 & 1.03 & 0.77 & 1.34 & - & - & - & - & - & - & - & - & - \\
\hline $\mathrm{Gd}$ & 1.65 & 3.71 & 3.19 & 2.88 & 3.65 & - & - & - & - & - & - & - & - & - \\
\hline Dy & 1.87 & 3.97 & 3.14 & 2.68 & 3.64 & - & - & - & - & - & - & - & - & - \\
\hline Ho & 0.44 & 0.83 & 0.62 & 0.54 & 0.76 & - & - & - & - & - & - & - & - & - \\
\hline $\mathrm{Er}$ & 1.15 & 2.46 & 1.65 & 1.48 & 2.18 & - & - & - & - & - & - & - & - & - \\
\hline $\mathrm{Yb}$ & 0.89 & 2.19 & 1.28 & 1.18 & 1.91 & - & - & - & - & - & - & - & - & - \\
\hline $\mathrm{Lu}$ & 0.13 & 0.31 & 0.19 & 0.17 & 0.29 & - & - & - & - & - & - & - & - & - \\
\hline
\end{tabular}


Table 2. Sm-Nd data used in the isochron of Figure 3.

\begin{tabular}{ccccccc}
\hline Sample & $\begin{array}{c}\text { Sm ppm } \\
\text { (error) }\end{array}$ & $\begin{array}{c}\text { Nd ppm } \\
\text { (error) }\end{array}$ & $\begin{array}{c}{ }^{147} \mathrm{Sm} /{ }^{144} \mathrm{Nd} \\
\text { (error) }\end{array}$ & $\begin{array}{c}{ }^{143} \mathrm{Nd} /{ }^{144} \mathrm{Nd} \\
\text { (error) }\end{array}$ & $\begin{array}{c}\mathrm{T}_{\mathrm{DM}} \mathrm{Ga} \\
\text { (error) }\end{array}$ & $\begin{array}{c}\boldsymbol{\varepsilon}_{\mathrm{Nd}} \\
\text { (2.3 Ga) }\end{array}$ \\
\hline \multirow{2}{*}{ T3-37 } & $\begin{array}{c}0.8 \\
(0.001)\end{array}$ & $\begin{array}{c}1.7 \\
(0.001)\end{array}$ & $\begin{array}{c}0.29499 \\
(0.00025)\end{array}$ & $\begin{array}{c}0.514245 \\
(0.000024)\end{array}$ & $\begin{array}{c}2.37 \\
(0.05)\end{array}$ & 2.4 \\
\hline \multirow{2}{*}{ T3-35 } & 1.804 & 5.930 & 0.18516 & 0.512622 & 2.26 & 3.1 \\
& $(0.001)$ & $(0.002)$ & $(0.00012)$ & $(0.000027)$ & $(0.11)$ & \\
\hline \multirow{2}{*}{ T2-1 } & 1.944 & 6.561 & 0.18932 & 0.512550 & 2.26 & 3.1 \\
& $(0.001)$ & $(0.002)$ & $(0.00012)$ & $(0.000029)$ & $(0.11)$ & \\
\hline \multirow{2}{*}{ S-183 } & 3.38 & 12.92 & 0.15898 & 0.512205 & 2.35 & 2.6 \\
& $(0.002)$ & $(0.003)$ & $(0.00012)$ & $(0.000033)$ & $(0.15)$ & \\
\hline
\end{tabular}

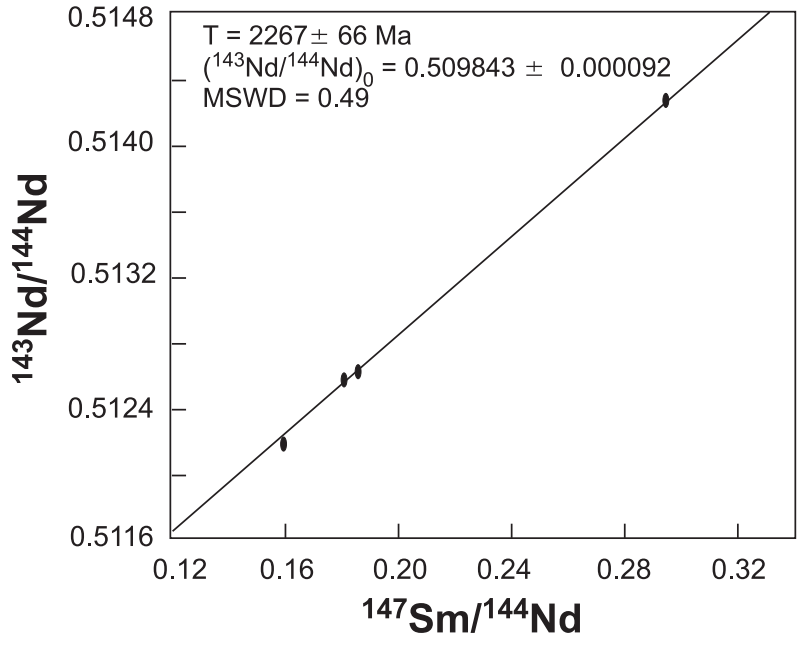

Figure 3. Sm-Nd whole rock isochron for selected metavolcanic rocks from the Vila Nova Group in the Ipitinga belt. See Table 2 for analytical results and text for explanation of sample selection criteria.

post-collision environments. The Carecuru intrusive suite which cuts the Ipitinga metamafic/ultramafic complex has been dated at $2.14 \mathrm{Ga}$ (Faraco et al., 2005). Zircon grains from a sample of syenogranite intrusive into amphibolite yielded ages of $2.655 \pm 4 \mathrm{Ma}, 2391 \pm 4 \mathrm{Ma}$ and a mean age of $2065 \pm 35 \mathrm{Ma}$ for three grains. Data for the Sm-Nd system yielded a $\mathrm{T}_{\mathrm{DM}}$ model age of $3.07 \mathrm{Ga}$ with $\varepsilon_{\mathrm{Nd}}(2.07)=-3.3$. The reactivation of ancient rocks now hidden beneath the VNG may explain the origin of this rock type.

In the Serra do Navio (Figure 2b) between 400 and 2,500 m of basal amphibolite and other metamafic rocks overly the metamorphic basement and are covered by $300-1,000 \mathrm{~m}$ of

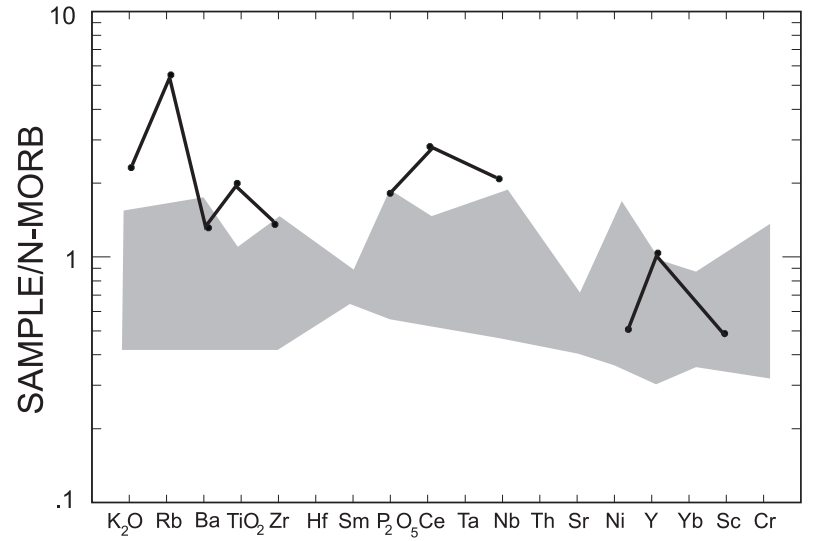

Figure 4. N-MORB (Pearce, 1982) normalized multi-element patterns for amphibolites of the Vila Nova Group. Shaded area, about 10 from the detailed study area in the Ipitinga belt, after Faraco (1990, 1997). Full circles, amphibolite from high-grade terrain south of the Oiapoque belt (data from this study).

quartz schists which host 3 - $15 \mathrm{~m}$ thick lenses of calc-silicate rocks, followed by $10-400 \mathrm{~m}$ of biotite schist and $5-200 \mathrm{~m}$ of graphite-rich schist containing lenses of calcic and manganiferous marble up to $200 \mathrm{~m}$ thick (Coelho Filho, and Coelho et al. in Spier and Ferreira Filho, 1999). The upwards variation of the sedimentary rocks suggests that the depositional environment evolved from near-shore to platform. The metamorphic grade is in the garnet zone of the amphibolite facies. Discrete shear zones cut the rocks, and syntectonic granites were intruded at this time. The whole assemblage was intruded by granite plutons (Scarpelli, 1966; Lima et al., 1974; Rodrigues et al., 1986; Ferran, 1988; Melo and Villas, 2001). 
South of the Serra do Navio, detrital sediments cover either the Bacuri metamorphic complex, or the old metamorphic basement (Figure 2). More than 1,000 m of basal quartzite with metaconglomerate lenses which contain pebbles derived from the Bacuri complex are overlain successively by $10-200 \mathrm{~m}$ of quartz schists, $115-385 \mathrm{~m}$ of coarse-grained quartz-rich metasediments, $5-100 \mathrm{~m}$ of sericite schist and $20-100 \mathrm{~m}$ of banded iron formation, all of which is finally capped by over $1,000 \mathrm{~m}$ of schist (Coelho et al. in Spier and Ferreira Filho, 1999). Minor intercalations of mafic metavolcanic rocks are not represented in the schematic diagram. This section was deposited closer to a continental mass than that of the Serra do Navio.

Intrusive but mainly undated granites in the Serra do Navio area are mainly calcic to calc-alkalic biotite tonalite, and alkali-calcic biotite monzogranite, syenogranite and alkali-feldspar granite (Figure 5). The more silicic potassic rocks are highly differentiated usually with accentuated $\mathrm{Nb}$ depletion relative to $\mathrm{Ce}$, typical of supra-subduction environments (Figure 6). A syn-orogenic batholith was dated at $2.14 \mathrm{Ga}$ (Faraco et al., 2004), while the very late Amapari granite was intruded at $1.99 \mathrm{Ga}$ (Oliveira et al., 2002).

The Igarapé do Breu chromitiferous metamafic/ ultramafic complex was included in the Vila Nova Group by Costa et al. (1974), Issler et al. (1974) and Lima et al. (1974) and was identified as an alpine-type deposit by Coelho et al. (in Spier and Ferreira Filho, 1999). These hypotheses have been questioned by Dardenne and Schobbehaus (2001) who treat the Bacuri and Igarapé do Breu occurrences together. Metadunite, metaperidotite and metaharzburgite with well-preserved primary plutonic textures and cores of the principal minerals found in the upper and middle reached of the Cupixi river were included as part of the Vila Nova Group by Montalvão (1985), who believed the rocks to be komatiites in spite of the absence of diagnostic volcanic textures. Mafic and ultramafic schists are present, however, in the area.

The inclusion in the Vila Nova Group of high-grade rocks, engulfed in granites, which are not found in other Vila Nova belts, seems to have been treated with some reserve, but this belt represents a geometrical extension of a belt including the Paramaca formation in French Guiana (Milési et al., 1995; BRGM, 2000). Apart from the ubiquitous amphibolite and quartzite, hornblende-biotite and cordierite-garnet schists and gneisses occurring in the northwestern part of the belt were attributed to the Cassiporé Sequence (Veiga et al., 1985) or the Serra Lombarda Group (Ferran, 1988).

In the area of the Salamangone gold mine in the Lourenço district, southeastern Serra Lombarda, the amphibolites have the geochemical signature of suprasubduction basalts to andesites, including a prominent subduction component represented by enrichment of light element lithophile elements and depletion of high fields strength elements, notably $\mathrm{Ta}$ and $\mathrm{Nb}$ (Nogueira, 2002). The host granitoids are calc-alkaline biotite tonalite and granodiorite, some of which have prominent foliations. Similar rocks are encountered in other parts of the Lourenço district. Rocks from the Salamangone mine were intruded at 2.16-2.2 Ga, and have the low initial ${ }^{87} \mathrm{Sr} /{ }^{86} \mathrm{Sr}$ ratios and low but positive $\varepsilon_{\mathrm{Nd}}(2.16-2.2)$ values expected for granite derived by rapid recycling of oceanic crust with very little or no participation of older continental crust (Nogueira, Bettencourt, Tassinari, 2000, 2001a, 2001b).

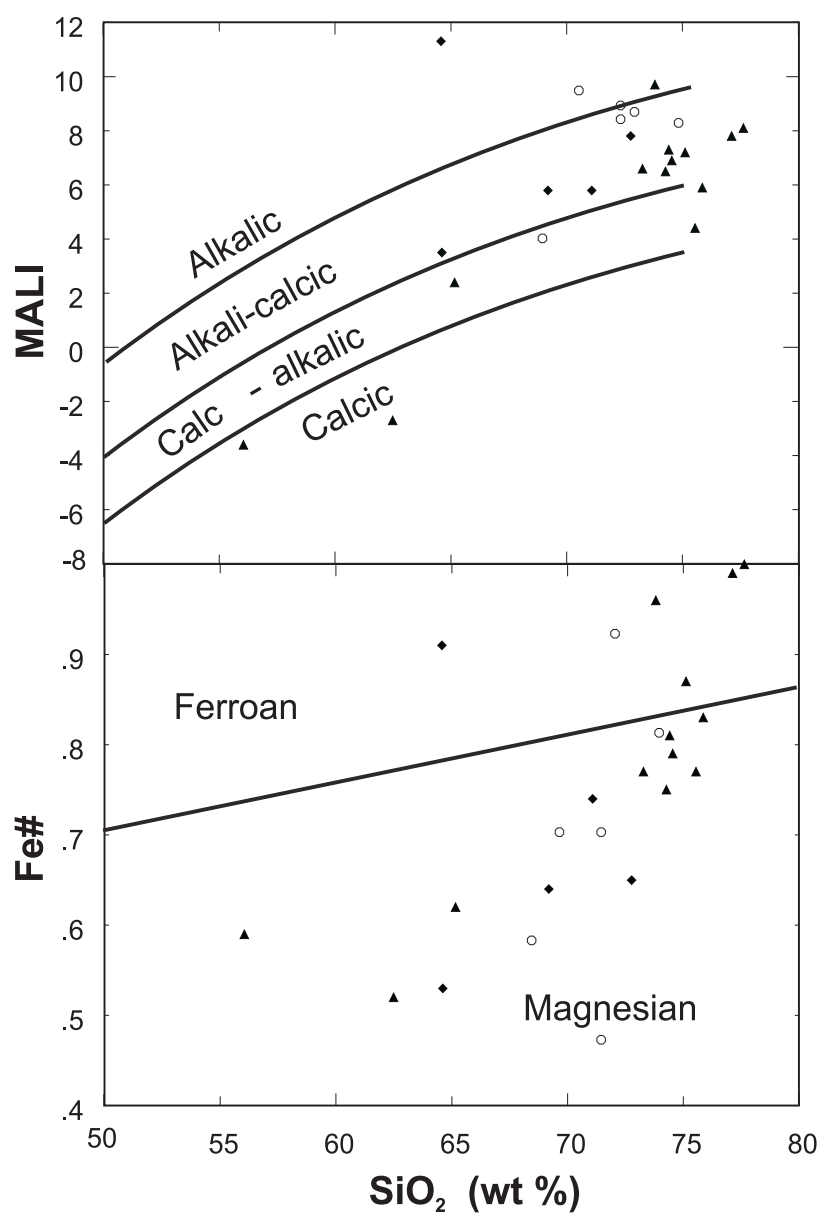

Figure 5. Compositions of granitoids from the detailed study area of the Ipitinga belt (open circles), the Serra do Navio segment of the Tumucumaque-Navio belt (full triangles), and the Tartarugalzinho segment of the LombardaTartarugalzinho belt (lozenges). MALI = modified alkali-lime index $\mathrm{Na}_{2} \mathrm{O}+\mathrm{K}_{2} \mathrm{O}-\mathrm{CaO} ; \mathrm{Fe} \#=\mathrm{FeO}_{\mathrm{t}} /\left(\mathrm{MgO}+\mathrm{FeO}_{\mathrm{t}}\right)$ (Frost et al., 2001). Data from this study. 


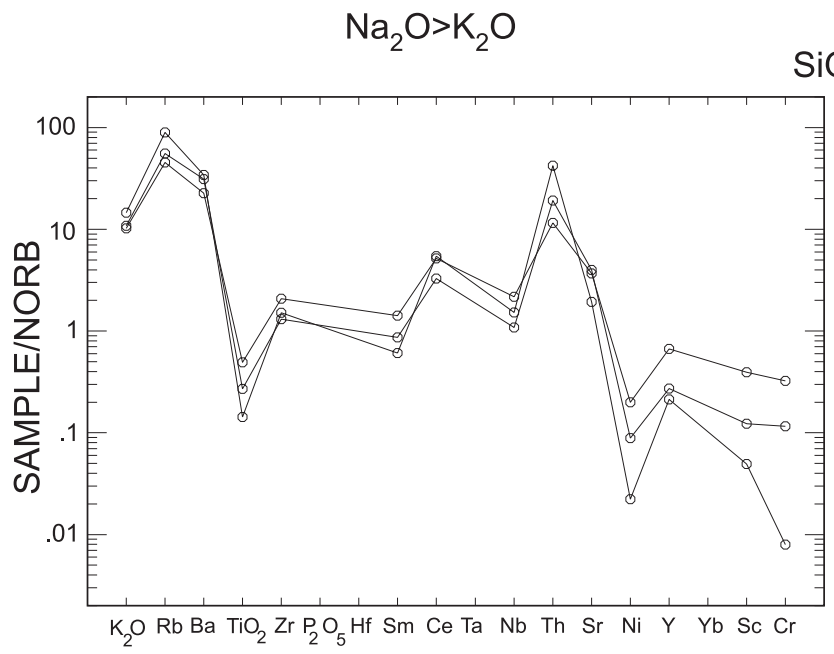

$\mathrm{SiO}_{2}>70 \%$

$\mathrm{K}_{2} \mathrm{O}>\mathrm{Na}_{2} \mathrm{O}$

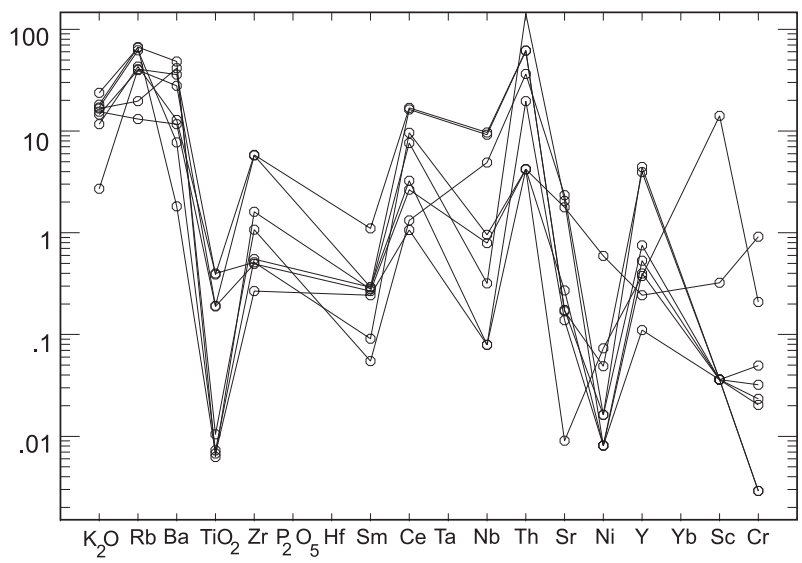

$70 \%>\mathrm{SiO}_{2}>50 \%$

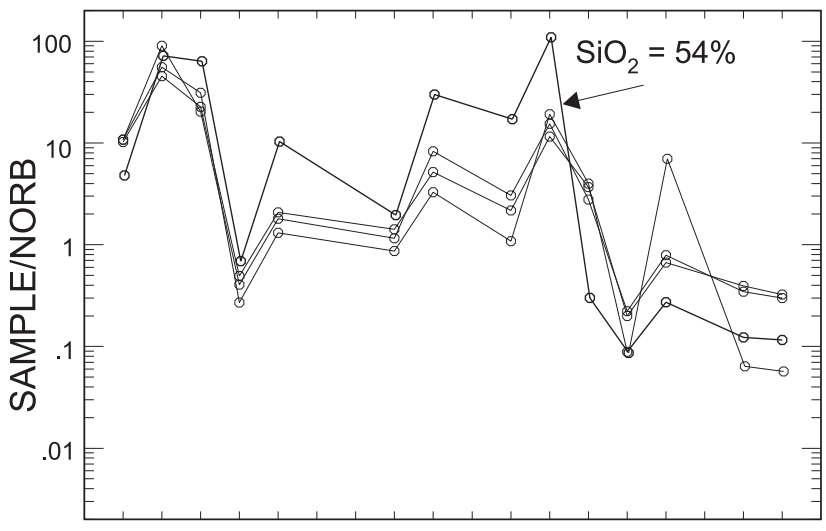

$\mathrm{K}_{2} \mathrm{O} \mathrm{Rb} \mathrm{Ba} \mathrm{TiO}_{2} \mathrm{Zr} \mathrm{P}_{2} \mathrm{O}_{5} \mathrm{Hf} \mathrm{Sm} \mathrm{Ce} \mathrm{Ta} \mathrm{Nb} \mathrm{Th} \mathrm{Sr} N i \quad \mathrm{Yb} \mathrm{Sc} C r$

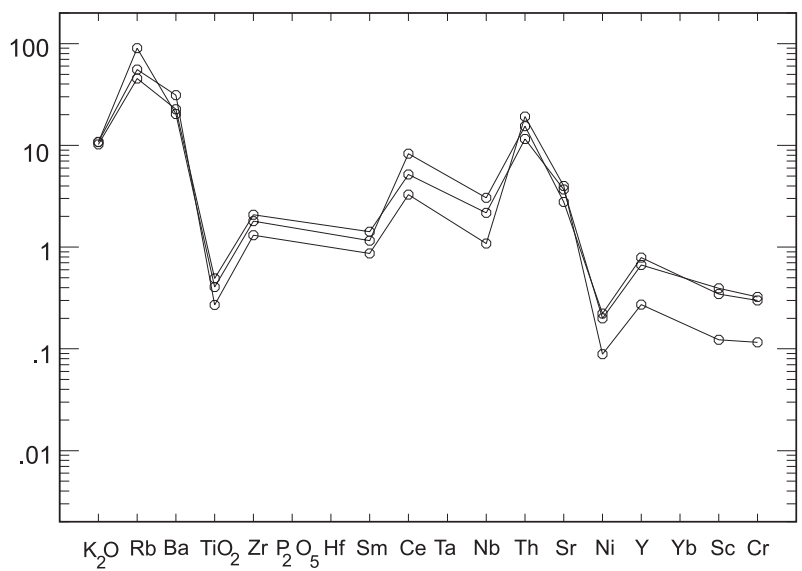

Figure 6. N-MORB normalized multi-element patterns for granitoids from the Navio segment of the Tumucumaque-Navio belt. Data from this study.

In the Camopi region on the Oiapoque river on a bifurcation of this belt many granitoids have $\mathrm{Nd} \mathrm{T}_{\mathrm{DM}}$ ages between 2.24 and $2.58 \mathrm{Ga}$ (Avelar et al., 2003), suggesting that both juvenile and mixed sources were envolved in their genesis.

The structural and metamorphic evolutions of this part of the belt are complex. Scarpelli (in Lima et al., 1974) identified regional, contact and dynamic metamorphic episodes in amphibolite facies, while Lima et al. (1991) found at least two deformations, the earlier regional under amphibolite facies, the later retrograde during shearing and thrusting.

In the Tartarugalzinho district in the southeastern part of the belt, a kilometric megaxenolith hosted by granite is composed mainly of schistose to gneissic metasediments, but mafic and possibly felsic metavolcanic rocks are also present (Jorge João et al., 1979). The host granites compose two intrusions, one formed by syeno- and monzogranite, the other by granodiorite and monzogranite.

The irregular disconnected exposures close to Oiapoque are a continuation of the Bonidoro of French Guiana. The continuation of this belt within Brazilian territory would follow the general direction of the Atlantic coast, and would include the region between Amapá and Calçoene. Apart from amphibolite, quartzite and schist (Costa et al., 1974), some rock descriptions refer to gabbro and diabase, which may belong to younger associations such as the $1.8 \mathrm{Ga}$ Avanavero suite (Norcross et al., 2000). 
A very incomplete multi-element pattern for an amphibolite (Figure 3) is spiky, and no conclusion can be drawn as to the possible tectonic environment. Lafon, Delor and Barbosa (2001) have identified 2.06 Ga charnockites in the Calçoene region.

\section{OTHER GREENSTONE-GRANITE BELTS OF THE GUYANA SHIELD}

Figure 7 presents a sketch of the main occurrences of late paleoproterozoic greenstone-granite belts with available ages. Together with the Brazilian occurrences, they form a large province abut 300 - $400 \mathrm{~km}$ wide which extends for about $1,500 \mathrm{~km}$ parallel to the Atlantic coastline.

Both lateral and vertical variations are observed in the Guaianese belts, which are frequently divided into two units (e.g. Gibbs and Baron, 1983; Gibbs, 1987). The lower unit is composed of mainly tholeiitic metavolcanic rocks, and may have already been deformed and metamorphosed before the deposition of the upper unit (Choudhuri, 1980; Milési et al., 1995). The upper unit consists of predominantly clastic meta-sedimentary rocks together with intermediate to felsic meta-volcanic rocks, with minor mafic and ultra-mafic metavolcanic rocks (Capdevilla et al., 1999). For Choudhuri (1980), Milési et al. (1995) and Vanderhaeghe et al. (1998), the upper unit was deposited at the margins of the metagreenstone assemblage, in pull-apart basins, or in basins formed between the greenstones, respectively.
The geochemistry of the mafic metavolcanic rocks, represented by chondrite-normalized REE patterns or by multi-element variation diagrams gives no clear indication of their tectonic environment. Typical flat to slightly LREEenriched patterns found in French Guiana (Milési et al., 1995; Capdevilla et al., 1999), in Suriname (Veemstra in Vletter, Aleva, Kroonenberg, 1998) and Guyana (Renner and Gibbs, 1987) are similar to those found in some MORB, back-arc basin basalt or island arc tholeiites, but are also typical of Archaean tholeiites in general (Veemstra, op. cit.). N-MORBnormalized spidergram patterns for metatholeiites from the Paramaca of French Guiana have well-defined $\mathrm{Ta}$ and $\mathrm{Nb}$ deficiencies and variable LILE behaviour (Milési et al., 1995), generally similar to those found in the Serra Lomarda amphibolites. Gibbs (1987) and Renner and Gibbs (1987) found patterns similar to MORB, others similar to IAT though without the $\mathrm{Ta}$ and $\mathrm{Nb}$ deficiencies which are common in these rocks, and yet others with continental basalt patterns. The possibility that different tectonic environments were involved in the deposition of these rocks cannot be excluded.

The 2.21 - 2.23 Ga gabbros of the Ile de Cayenne Series or Complex in French Guyana are regarded as part of the early oceanic magmatic events (Delor et al., 2003) while the 2.18 2.13 Ga tonalitic to granodioritic gneisses (Milési et al., 1995; Delor et al., 2003) are attributed to multi-phase island arc magmatism. The latter rocks are contemporaneous with the granitoids which intrude the Lomarda segment in Brazil. The

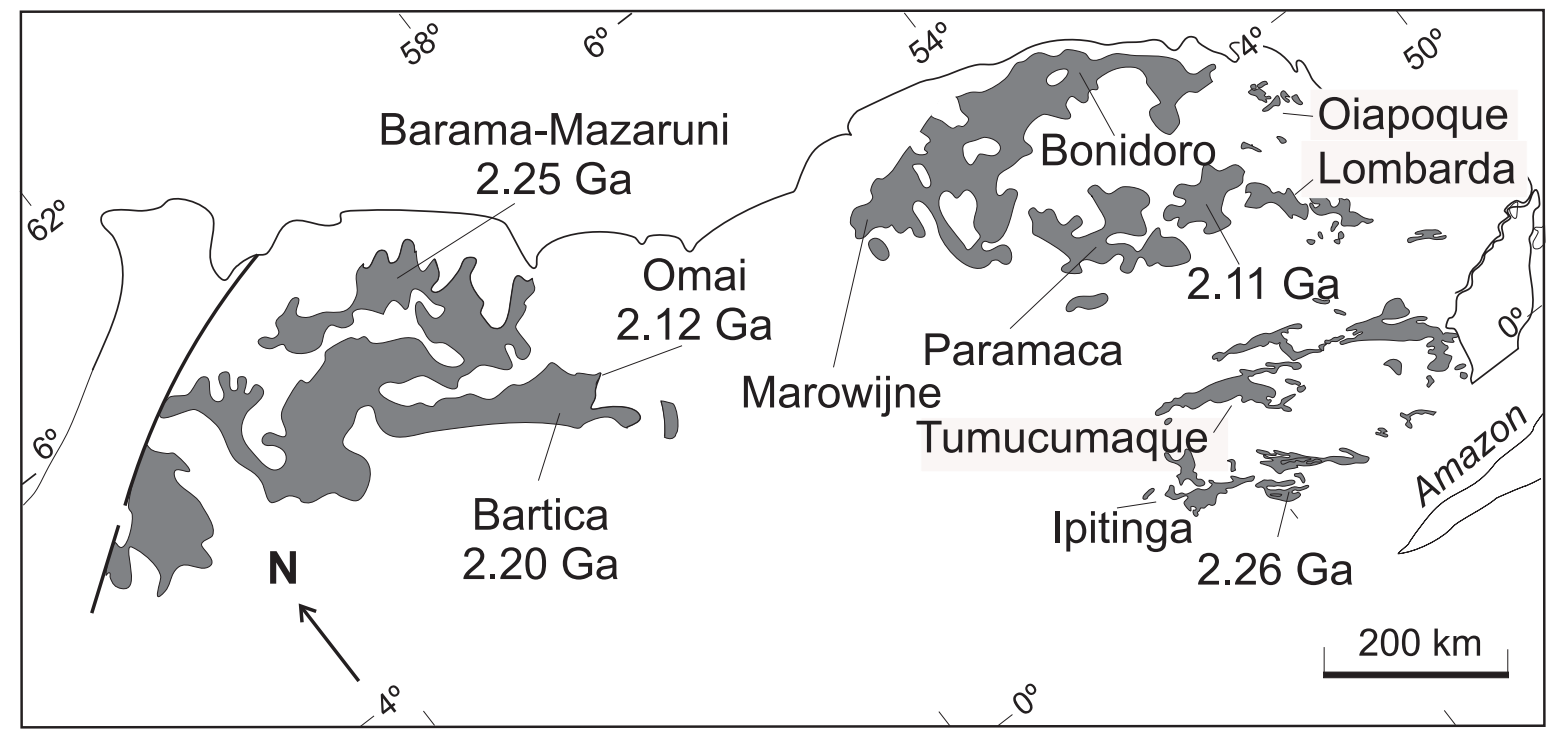

Figure 7. The granite-greenstone belts of the Guyana Shield. Base map modified from Gibbs (1987) and Faraco, Marino and Vale (2000). Sources of ages for Brazilian belts are given in the text. Other ages of greenstone or intrusives: Paramaca - Gruau et al. (1985); Omai - Norcross et al. (2000); Bartica - Caen-Vachette (1988); Barama-Mazaruni - Gibbs and Olsewski (1982). 
vast majority of dated Transamazonian plutons in the Guyana Shield, however, are younger and compose at least two generations (Milési et al., 1995; Vletter, Aleva, Kroonenberg, 1998), the first syn-tectonic, therefore foliated, and more sodic, the second, late- to post-tectonic, more potassic and sometimes intruded into shallow crustal levels. Both generations are accompanied by gabbro-diorite-tonalitegranodiorite suites. Subduction followed by continental collision is the obvious scenario for the latest stage of formation of these belts. The relationship between the latest post-collision felsic rocks, and the first manifestation of the anorogenic Uatumã volcanism which probably started at about $1.9 \mathrm{Ga}$ (Tassinari et al., 2000) is still not clear.

\section{EBURNEAN GREENSTONE-GRANITE BELTS IN THE WEST AFRICAN CRATON}

The belts occur in an area about 2,000 km long and $600 \mathrm{~km}$ wide. A number of attempts have been made to reconstruct the paleogeography before brasiliano-age crustal movements and the later opening of the Atlantic Ocean. A pioneering attempt was made by McConnell (1969), and Caen-Vachette (1988) and Delor et al. (2000) have made important contributions. In the reconstruction proposed by Ledru et al. (1994) the Guaianese belts probably align with central and eastern belts of the West African Craton (Figure 8), though the alignment is not straight. In the African belts, the medium-grade Dabakalian metamorphic complex and lower-grade volcano-sedimentary associations of a similar age are found (Boher et al., 1992; Taylor et al., 1992; Hirdes et al., 1996; Hirdes and Davis, 1998).

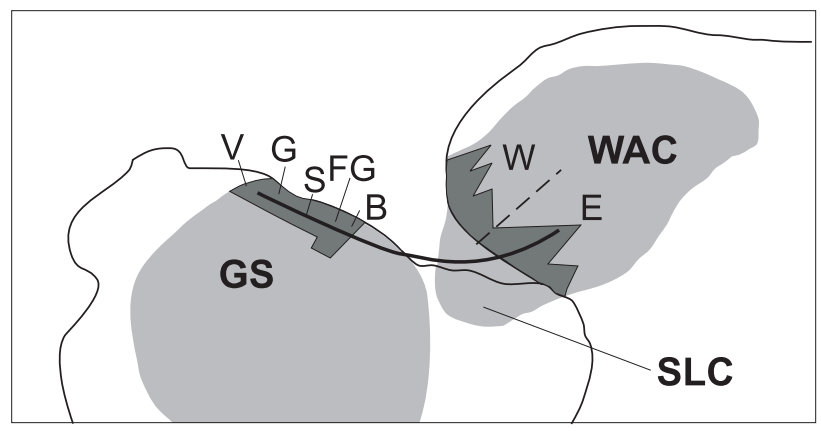

Figure 8. Paleogeographic reconstruction at about $2.0 \mathrm{Ga}$ suggested by Ledru et al. (1994). Cratonic areas in midgrey: GS - Guyana Shield; SLC - São Luiz Craton; WAC - West African Craton. Darker grey areas, schematic representation of areas of the greenstone-granite belts in the Guyana Shield, V - Venezuela, G - Guyana, S - Surinam, FG - French Guiana, B - Brazil; W and E - western and eastern belts in the West African Craton.
A wealth of high precision ages obtained over the last two decades now allows the ca. $2.0 \mathrm{Ga}$ Eburnean to be divided into pre-Birimian, Birimian (2.19-2.15 Ga), Bandamian $(2.12-2.10 \mathrm{Ga})$ and post- Bandamian phases. The Dabakalian complex presents some evidence for an early event of crustal accretion (Gasquet et al., 2003) with 2.21 - 2.31 Ga pre-Birimian ages registered in detrital zircon from metasediments, and in inherited zircon and zircon cores within Birimian granitoids. Other older ages around $2.25 \mathrm{Ga}$ are recorded in reworked archaean gneisses, and are suggested to represent the earliest manifestation of paleoproterozoic heating (Kouamelan, Peucat, Delor, 1997). Our Sm-Nd isochron age of $2.26 \mathrm{Ga}$ for Ipitinga metavolcanic rocks falls within the same age range, and may confirm this earlier event.

A major mafic-dominated volcanic association with geochemical characteristics similar to those of modern oceanic plateaus was formed at about $2.1 \mathrm{Ga}$ (Abouchami et al., 1990; Boher et al., 1992). As an aside, nowhere is there any direct evidence for the very thick (often greater than $30 \mathrm{~km}$ ) volcanic and plutonic associations which would be expected if a direct comparison with modern oceanic plateaus is valid.

As in most of the Guyana Shield, two main rock units with lateral and vertical variations are usually identified, but stratigraphic relationships are controversial, and the volcanic and sedimentary units may have been deposited in separate basins (Leube et al., 1990). A major apparent difference, however, is the presence of $2.20 \mathrm{Ga}$ felsic metavolcanic rocks in the oldest dated unit (Hirdes et al., 1996), in which mafic metavolcanic rocks usually predominate. Chondritenormalized REE patterns and N-MORB-normalized spidergrams (Abouchami et al., 1990) are as diverse as those found for Guyana Shield rocks. Meta-ultramafic rocks have been identified as high-Mg tholeiites (Mortimer, 1992; Sylvester and Attoh, 1992) or komatiites (Leube et al., 1990; Caby, Delor, Agoh, 2000). The plutonic associations are in many ways directly comparable to those of the Guyana Shield, with earlier suites of mainly sodic rocks, and later suites of potassic rocks which mainly intrude the metavolcanic formations.

\section{DISCUSSION AND CONCLUSIONS}

The limited detailed information on the paleoproterozoic granite-greenstone terrains of northern Brazil point to similarities to and differences from their Guianese and West African counterparts. While Brazilian belts which have continuity with those of the Guianas record destructive margin volcanism and plutonism, the southwesternmost Ipitinga and Tumucumaque-Navio belts have features which indicate deposition of Vila Nova Group rocks at constructive and passive continental margins, respectively. The Ipitinga rocks 
represent an early magmatic event at about $2.27 \mathrm{Ga}$ which may have its equivalent in West Africa, while the available ages for the other Brazilian belts conform to the previously established pattern of major activity around $2.1 \mathrm{Ga}$.

As has already been pointed out by other research workers, the paleoproterozoic events in the former megaprovince contributed to a major crustal addition through a typical Wilson cycle. In the Ipitinga belt, the time interval between the first manifestation of oceanic magmatism and the collision-related granite magmatism is around $200 \mathrm{Ma}$. Subduction and collision-related magmatism seem to follow in close succession, within an interval of around $100 \mathrm{Ma}$. Both juvenile additions and recycling of ancient crust were involved in the genesis of the granites. At present, the available data on the megaprovince point to the opening of small ocean basins (probably more than one), and subsequent subduction as the salient features of this important phase of crustal growth, while transcurrent movements were important for the development of the present stuctures.

\section{ACKNOWLEDGMENTS}

The authors thank the Companhia de Pesquisas de Recursos Minerais - Serviço Geológico do Brasil for continued support during the research. The cooperation of the technical staffs of the Centro de Pesquisas Geocronológicas and the Laboratório de Fluorescência de Raios-X of the Instituto de Geociências, Universidade de São Paulo, is gratefully acknowledged. Support for the study of isotope geochemistry was provided by the Fundação de Amparo à Pesquisa no Estado de São Paulo (FAPESP) through contract $n^{\circ}$. 94/3450-4. Ian McReath acknowledges a Research Fellowship of the Conselho Nacional de Pesquisa. Maria Telma Lins Faraco was awarded a CAPES Post Graduate Sandwich Scholarship. Carlos Alberto Spier kindly supplied preprints of his articles, and cleared up doubts about geological details in the Serra do Navio area, now lost to direct observation. Alcides Nóbrega Sial and Jorge Silva Bettencourt commented on an early draft, and João Batista Teixeira and an anonymous reviewer are thanked for their rigourous checking of the manuscript and their constructive comments.

\section{REFERENCES}

ABOUCHAMI, W.; BOHER, M.; MICHARD, A.; ALBAREDE, F. A major 2.1Ga event of mafic magmatism in West Africa: An early stage of crustal accretion. Journal of Geophysical Research, v. 95, B11, p. 17, 609-617, 625, 1990.

AVELAR, V. G.; LAFON, J. M.; DELOR, C. Geocronologia
$\mathrm{Pb}-\mathrm{Pb}$ em zircão e $\mathrm{Sm}-\mathrm{Nd}$ em rocha total da porção centronorte do Amapá. Implicações para a evolução geodinâmica do Escudo das Guianas. In: SIMPÓSIO DE GEOLOGIA DA AMAZÔNIA, 8., 2001, Belém. Resumos Expandidos... Belém: SBG, 2001. 1 CD-ROM.

AVELAR, V. G.; LAFON, J. M.; DELOR, C.; GUERROT, C.; LAHONDÈRE, D. Archaean crustal remnants in the eastermost part of the Guiana Shield: $\mathrm{Pb}-\mathrm{Pb}$ and $\mathrm{Sm}-\mathrm{Nd}$ geochronological evidence for Mesoarchaean versus Neoarchaean signatures. In: ROSSI, P.; LAFON, H.-M.; VASQUEZ, M. L. Spécial Bouclier guyanais. Geologie de la France. Orléans: BRGM/ SGF, 2003. v. 2003, n. 2-4, p. 83-99.

BOHER, M.; ABOUCHAMI, W.; MICHARD,A.;ALBAREDE, F; ARNDT. N. Y. Crustal growth in West Africa at 2.1Ga. Journal of Geophysical Research, v. 97, B1, p. 345-369, 1992.

BRGM. Carte Geologique de la France à 1:500.000. 2. ed. [France]: Service Geologique Nationale, 2000. 1 mapa. Escala 1:500.000.

CABY, R.; DELOR, C.; AGOH, O. Lithologie, structure et métamorphisme des formations birimiennes dans le region d'Odienné (Côte d'Ivoire): role majeur du diapirisme des plutons et des d'chrochement en bordure du craton de Man. Journal of African Earth Sciences, v. 30, p. 351-374, 2000.

CAEN-VACHETTE, M. Le craton west-africain et le bouclier guyanais: un seul craton du Proterozoique inferieur? Journal of African Earth Sciences, v. 17, p. 479-488, 1988.

CAPDEVILA, R.; ARNDT, N.; LETENBRE, J.; SAUVAGE, J. J. Diamonds in volcaniclastic komatiite from French Guiana. Nature, v. 399, p. 456-458, 1999.

CARVALHO, J. M. de A. Projeto mapas metalogenéticos, e de previsão de recursos minerais da folha NA/NB.22 (Macapá). Belém: DNPM/CPRM, 1984. Mapas. Escala 1:1.000.000.

CARVALHO, J. M. de A.; FARACO, M. T. L.; KLIEN, E. L. Carta geoquímico-metalogenética de ouro do Amapá/NW do Pará, escala 1;500.000: Mapa e Nota Explicativa. Belém: CPRM, 1995. $4 \mathrm{p}$.

CHOUDHURI, A. The early proterozoic greenstone belt of the northern Guiana Shield, South América. Precambrian Research, v. 13, p.363-374, 1980.

COSTA, J. L. et al. Projeto Norte da Amazônia, domínio Oiapoque - Jarí. Belém: DNPM/ CPRM, 1974. 7 v. (Relatório Final). 
DARDENNE, M. A.; SCHOBBENHAUS, C. Metalogênese do Brasil. Brasília: Editora Universidade de Brasília, 2001.329 p.

DELOR, C.; FARACO, M. T.; FRAGA, L.; LAFON, J. M.; DE ROEVER, E.; ROSSI, P.; VIDAL, M. Synthesis of the North Amazonian Precambrian Shield (SYNAPS) and transatlantic correlations: a geological framework for the analysis of the Precambrian crustal growth. In: INTERNATIONAL GEOLOGICAL CONGRESS, 31., 2000. Anais... Rio de Janeiro: CPRM, 2000. 1 CD-ROM.

DELOR, C.; LAHONDÈRE, D.; EGAL, E.; LAFON, J.-M.; COCHERIE, A.; GURROT, C.; ROSSI, P.; TRUFFERT, C.; THÉVENIAUT, H.; PHILLIPS, D.; AVELAR, V. G. de. Transamazonian crustal growth and reworking as revealed bu the 1:500.000-scale geological map of French Guiana. In: ROSSI, P.; LAFON, H. M.; VASQUEZ, M. L. Spécial Bouclier guyanais. Geologie de la France. Orléans, BRGM/SGF, p. 5-57, 2003.

FARACO, M. T. L. Evolução petrológico-geoquímica das rochas da Suite Metamórfica Vila Nova na Serra do Ipitinga (NW do Pará), 1990. 1 v. Dissertação (Mestrado) - Centro de Geociências, Universidade Federal do Pará, Belém, PA.

FARACO, M. T. L. Evolução petroquímico-metalogenética dasa rochas e mineralizações associadas à Suíte Vila Nova na Serra do Ipitinga (NW do Pará). 1997. 1v. Tese (Doutorado) - Centro de Geociências, Universidade Federal do Pará, Belém, PA.

FARACO, M. T. L.; McREATH, I.; COSTA, M. L. da; Geoquímica dos elementos terras raras das formações ferríferas da suíte metamórfica Vila Nova na Serra do Ipitinga (NW do Pará). Geochimica Brasiliensis, v. 5, p. 89-100, . 1992.

FARACO, M. T. L.; FUZIKAWA, K.; McREATH, I.; PIMENTA, M. Estudo de inclusões fluidas em rochas da Suíte Metamórfica Vila Nova na Serra do Ipitinga, NW do Pará. Geochimica Brasiliensis, v. 9, p. 173-183,. 1995.

FARACO, M. T. L.; MARINHO, P. A. da C.; VALE, A. M.; MOURA, C. V. Corpo máfico-ultramáfico no Distrito de Ipitinga - Reserva Nacional de Cobre e seus associados. In: CONGRESSOBRASILEIRODEGEOLOGIA, 42., 2004,Araxá. Resumos .... Araxá; SBG, 2004. 1 CD-ROM.

FARACO, M. T. L.; MARINHO, P. A. da C.; VALE, A. G.; MOURA, C. A. V.; MACAMBIRA, M. J. B.; PIMENTAL, M. Novos dados geocronológicos no Amapá - NNW do Pará e sua contribuição no entendimento geodinâmico no SE do
Escudo das Guianas. Submitted.

FERRAN, A. de. Depostos de ouro de Salamangone e Mutum, Calçoenem Anapá, In; SCHOBBENHAUS, C.; GOLD, C. E. S. (Coords) Principais Dépositos Minerais do Brasil. Brasília, DNPM/CVRD, 1988. v. 3, p. 581-588.

FROST, B.D.; BARNES, C. G.; COLLINS, W. J.;ARCULUS, R. J.; ELLIS, D. J.; FROST, C. D. A geochemical classification for granitic rocks. Journal of Petrology, v. 42, p. 2033-2048, 2001.

GIBBS, A. K. Proterozoic volcanic rocks of the northern Guiana Shield, South America. In: PHARAOH, T. C.; BECKINSALE, R. D.; RICKARD, D. (cords) Geochemistry and mineralization of Proterozoic volcanic suites. London: Geological Society of London, 1987. p. 275-288. (Special Publication, $\mathrm{n}^{\circ}$ 33).

GIBBS, A. K.; BARRON, C. N. The Guiana Shield revisited. Episodes, v. 2, p. 7-14. 1983.

GIBBS, A. K.; OLSZESKI, W. J. Jr. Zircon U-Pb ages of the Guiana greenstone-gneiss terrane. Precambrian Research, v. 30, p. 63-80, 1982.

GRUAU, G.; MARTIN, H.; LEVEQUE, B.; CAPDEVILA, R. $\mathrm{Rb}-\mathrm{Sr}$ and $\mathrm{Sm}-\mathrm{Nd}$ geochronology of Lower Proterozoic granite-greenstone terrains in French Guiana, South America. Precambrian Research, v. 30, p. 63-80, 1985.

HASUI, Y.; HARALI, N. L. E.; SCHOBBENHAUS, C. Elementos geofísicos e geológicos da Região Amazônica. In: SIMPÓSIO AMAZÔNICO, 2, 1984. Manaus. Anais... Manaus: SBG, 1984. v. 1, p. 129-148.

HIRDES, W.; DAVIS, D. W. Zircon ages of extrusive volcanism in the Birrimian Supergroup of Ghana/ West Africa. Journal of African Earth Sciences, v. 27, p. 291-294, 1998.

HIRDES, W.; DAVIS, D. W.; LÜDTKE, G.; KORIAN, G. Two generations of Birimian (Paleoproterozoic) volcanic belts in northeastern Côte d 'Tvoire (West Africa): consequences for the "Birimian Controversy". Precambrian Research, v. 80, p. 173-191, 1996.

HORIKAVA, E.; FEREIRA FILHO, C. F. Corpos máficoultramáficos da região da Serra do Navio AP. In: SIMPÓSIO DE GEOLOGIA DA AMAZÔNIA, 8., 2003. Manaus. Resumos...Manaus: SBG, 2003. 1 CD-ROM.

ISSLER, R. S.; ANDRADE, A. R. F. de; MONTALVÃO, R. M. G. de; GUIMARÃES, G.; SILVA, G. C. de; LIMA, M. I. C. 
de. Projeto RADAM, Folha AS 22 Belém. Rio de Janeiro: DNPM, 1974. v. 5. (Levantamento de Recursos Naturais).

JORGE JOÃO, X. da S.; FRIZZO, S. J.;MARINHO, P. A.; CARVALHO, J. M. de A.; SILVA NETO, C. S.; SOUZA, A. N.;; GUIMARÃES, L. R. Projeto Sudoeste do Amapá. Belém: DNPM/CPRM,. 1978., v. 1-A, 224 p. (Relatório Final).

JORGE JOÃO, X. da S.; CARVALHO, J. M. A. de; VALE, A. G.; FRIZZO, S. J.; MARTINS, R. C. Projeto Falsino, Belém: DNPM/CPRM. 1979. v. 1, 199 p. (Relatório Final).

KOUAMELAN, A. N.; PEUCAT, J. J.; DELOR, C. Reliques archéenes $(3,15 \mathrm{Ga})$ au sein du magmatisme birrimien $(2,1 \mathrm{Ga})$ de Côte dÍvoire, craton oust-africain. Comptes Rendues Academie Sciences Paris, v. 324 (iia), p. 719-717. 1997.

LAFON, J. M.; DELOR, C.; BARBOSA, O. S.Granulitos tarditransamazônicos $(1,06 \mathrm{Ga})$ na região norte do Estado da Amapá: o charnoquito de Calçoene. In: SIMPÓSIO DE GEOLOGIA DA AMAZÔNIA, 7., 2001. Belém. Resumos Expandidos...Belém: SBG, 2001. 1 CD-ROM

LEDRU, P.; JOHAN, V.; MILÉSI, J. P.; TEGVEY, M. Markers of the final stages of the Paleoproterozoic collision: evidence for a $2 \mathrm{Ga}$ continent involving circum-South Atlantic provinces. Precambrian Research,. v. 69, p. 169-191, 1994.

LEUBE, A.; HIRDES, W.; MAUER, R.; KESSE, G. O. The early Proterozoic Birimian Supergroup of Ghana and some aspects of its associated gold mineralization. Precambrian Research, v. 46, p. 139-165, 1990.

LIMA, M. I. C. et al. Cinturões granulíticos da Craton Amazônico. In. SIMPÓsIO DE GEOLOGIA DA AMAZÔNIA, 1., 1982. Belém. Anais....Belém: SBG, 1982. v. 1, p. 147-162.

LIMA, M. I. C.; MONTALVÃO, R. M. G.; ISSLER, R. S.; OLIVEIRA, A. de S.; BASEI, M. A. S.; ARAÚJO, H. J. T. de; SILVA, G. G. Projeto RADAM, Folha NA/NB 22 Macapá. Rio de Janeiro: DNPM, 1974. v. 6. (Levantamento de Recursos Naturais).

LIMA, M. I. C.; BEZERRA, P. E. L.; ARAÚJO, H. J. T. de; SIGA JÚNIOR, O.; MONTALVÃO, R. M. Sistematização da geologia do Estado do Amapá. In: SIMPÓSIO DE GEOLOGIA DAAMAZÔNIA, 3., 1991. Belém. Anais... Belém:SBG, 1991. p. 322-335.

MATTOS, A. A.; SPIER, C. A.; SOARES, J. W. Depósitos de cromite da região do rio Vila Nova. In: CONGRESSO BRASILEIRO DE GEOLOGIA, 37., 1992. São Paulo. Anais...São Paulo: SBG, 1992. v. 1, p. 246-247.

McCONNELL, R. B. Fundamental foult zones in the Guiana and West African Shields in relation to presumed axes of Atlantic spreading. Bulletin of the Geological Society of America, v. 80, p. 1775-1782, 1969.

McREATH, I.; FARACO, M. T. L. Sm-Nd and Rb-Sr systems in part of the Vila Nova Metamorphic Suite, Northern Brazil. In: SOUTH AMERICAN SYMPOSIUM ON ISOTOPE GEOLOGY, 1., 1997. Campos de Jordão. Extended Abstracts ... Campos do Jordão, 1996, p. 194-196.

MELO, L. V. de; VILLAS, R. N. N. O depósito aurífero Amapari, Amapá: fluidos mineralizantes e tipologia. In: SIMPÓSIODE GEOLOGIADAAMAZÔNIA, 7., 2001. Belém. Resumos Expandidos. . .Belém, SBG, 2001. 1 CD-ROM.

MILÉSI, J-O.; EGAL, E.; LEDRU, P.; VERNHET, Y.; THIÉGLEMONT, D. M.; COCHERIE, A.; TEGYEY, M.; MARTEL-JANTIN, B.; LAGNY, P. Les minéralisations du Nord de la Guyane français dans leur cadre géologique. Chronique de la Recherche Minière, n. 518, p. 5-58. 1995.

MONTALVÃO, R. M. G. Petrologia das rochas máficoultramáficas do Supergrupo Vila Nova (greenstone belt) e Grupo Parima (greenstone belt) e encraves na região do Parima. In: SIMPÓSIO DE GEOLOGIADAAMAZÔNIA, 2 ., 1985. Belém. Anais ...Belém: SBG, 1985. v. 1, p. 110-123.

MONTALVÃO, R. M. G; TASSINARI, C.C. G. Geocronologia precambriana do Território Federal do Amapá. In: SIMPÓSIO AMAZÔNICO, 2., 1984. Manaus. Anais... Manaus: 1984. p. 53-57.

MORTIMER, J. Lithostratigraphy of the early Proterozoic Toumodi volcanic group in Central Côte d'Ivoire: Implications for birimian stratigraphuc models, Journal of African Earth Sciences, v. 14, p. 81-91, 1992.

NOGUEIRA, S. A. A. Contribuição ao estudo metalogenético do depósito de ouro de Salamangone, distrito aurífero de Lourenço, Amapá. 2002. 230 p. Tese (Doutorado)- Instituto de Geociências, Universidade de São Paulo, São Paulo.

NOGUEIRA, S. A. A.; BETTENCOURT, J. S.; TASSINARI, C. C. G. Geochronology of the granitoid-hosted Salamangone gold deposit, Lourenço District, Amapá, Brazil. Revista Brasileira de Geociências, v. 30, p. 261-264. 2000. 
NOGUEIRA, S. A. A.; BETTENCOURT, J. S.; TASSINARI, C. C. G. The Salamangone paleoproterozoic Au-deposit, Lourenço District, Amapá, Brazil: U-Pb, Sm-Nd, Rb-Sr, Pb$\mathrm{Pb}$ and $\mathrm{K}-\mathrm{Ar}$ isotopic signatures. In: SOUTH AMERICAN SYMPOSIUM ON ISOTOPE GEOLOGY,3., 2001. Pucón. Extended Abstracts ... Pucón: Sociedad Geologica de Chile, 2001.p. 504-507.

NOGUEIRA, S. A. A.; BETTENCOURT, J. S.; TASSINARI, C. C. G. The Salamangone Paleoproterozoic Au-deposit, Amapá, Brazil: a granitoid-hosted lode gold deposit. In: CONGRESSO LATINO-AMERICANO DE GEOLOGIA, 11., / CONGRESSO URUGUAYO DE GEOLOGIA, 3., 2001(b). Montevideo. Abstracts . . Montevideo. 2001. p. 6.

NORCROSS, C.; DAVIS, D. W.; SPOONER, E. T. C.; RUST, A. U-Pb and $\mathrm{Pb}-\mathrm{Pb}$ age constraints on Paleoproterozoic magmatism, deformation and gold mineralization in the Omai area, Guyana Shield. Precambrian Research, v. 102, p. 69-86, 2000.

OLIVEIRA, E. C.; LAFON, J. M.; GIOIA, S. M.; PIMENTEL, M. M. Implementação do método Sm-Nd para minerais metamórficos e sua aplicação em rochas da região central do Amapá, sudeste do Escudo as Guianas. In: CONGRESSO BRASILEIRO DE GEOLOGIA, 41., 2002. Recife. Anais... .Recife: SBG, p. 502.

PAIVA, G. de. Ferro. Território Federal do Amapá. Rio de Janeiro: DFPM. Boletim, n. 79, p. 117-118, 1946.

PEARCE, J. A. Trace element characteristics of lavas from destructive plate boundaries. In: THORPE, R. S. (ed.) Andesites: Orogenic andesites and related rocks. Chichester,: Wiley, 1982. p. 525-548.

PIMENTEL, M. M.; FERREIRAFILHO, C. F.; SPIER, C. A. Estudo Sm-Nd do complexo máfico-ultramáfico Bacuri, Amapá: idade de intrusão, metamorfismo e natureza do magma original. Revista Brasileira de Geociências, v. 30, p. 371-376, 2002.

PRICHARD, H. M.; SÁ, J. H. S.; FISHER, P. C. Platinumgroup mineral assemblages and chronite compositions in the altered and deformed Bacuri complex, Amapá, Northeastern Brazil. Canadian Mineralogist, v. 39, p. 377-396, 2001.

RENNER, R.; GIBBS, A. K. Geochemistry and petrology of metavolcanic rocks of the early Proterozoic Mazaruni greenstone belt, northern Guyana. In: PHARAOH, T. C.; BECKINSALE, R. D.; RICKARD, D. Geochemistry and mineralization of Proterozoic volcanic suites. London: Geological Society of London, 1987, p. 280-300. (Special Publication, n. 33).

RODRIGUES, O. B.; KOSUKI, R.; COELHO FILHO, A. Distrito manganesífero de Serra do Navio, Amapá. In: SCHOBBENHAUS, C.; COELHO, C. E. S. (Coords) Principais Depósitos Minerais do Brasil. Brasília: DNPM, 1986. v. 2, p. 167-175.

ROSA-COSTA, L. T.; RICCI, P. S. F.; LAFON, J. M.; VASQUEZ, M. L.; CARVALHO, E. L.; KLEIN, E. V.; MACAMBIRA, E. M. B. Geology and geochronology of Archaean and Paleoproterozoic comains of southwestern Amapá and northwestern Pará, Brazil, southeastern Guiana shield. In: ROSSI, P.; LAFON, H. M.; VASQUEZ, M. L. Spécial Bouclier guyanais. Geologie de la France. Orléans,: BRGM/SGF, 2003. n. 2-3-4, p. 101-120.

SATO, K.; TASSINARI, C. C. G. Principais eventos de acresção continental no Craton Amazônico baseados em idade modelo $\mathrm{Sm}-\mathrm{Nd}$, calculada em evolução de estágio único e estágio duplo. In: COSTA, M. L. da; ANGÊLICA, R. S. (Coords) Contribuições à Geologia da Amazônia. Belém: FINEP/SBG-NO, 1997.p. 91-142.

SCARPELLI, W. Aspectos genéticos e metamórficos do Distrito da Serra do Navio. Rio de Janeiro: DGM, 1966. p. 37-55. (Publicação avulsa, $\mathrm{n}^{\circ} 41$ ).

SPIER, C. A.; FERREIRA FILHO, C. F. Geologia, estratigrafia e depósitos minerais do Projeto Vila Nova, Escudo das Guianas. Revista Brasileira de Geociências, v. 29, p. 173-178, 1999.

SPIER, C. A.; FERREIRA FILHO, C. F. The chromite deposits of the Bacuri mafic-ultramafic layered complex, Guiana Shield, Amapá State, Brazil. Economic Geology, v. 96, p. 817-835, 2001.

SYLVESTER, P. J.; ATTOH, K. Lithostratigraphy and composition of $2.1 \mathrm{Ga}$ greenstone belts of the West African Craton and their bearing on curstl evolution and the Archaean-Proterozoic boundary. Journal of Geology, v. 100, p. 377-393, 1992.

TASSINARI, C. C. G.; BETTENCOURT, J. S.; GERALDES, M. C.; MACAMBIRA, M. J. B.; LAFON, J. M. The Amazon Craton. In: CORDANI, U. G.; MILANI, E. J.; THOMAZ FILHO, A.; CAMPOS, D. A. (Eds) Tectonic Evolution of South America. Rio de Janeiro: International Geological Congress, 31. 2000. p. 41-95. 
TAYLOR, P. N.; MOORBATH, S.; LEUBE, A.; HIRDES, W. Early Proterozoic crustal evolution in the Birimian of Ghana: constraints from geochronology and isotope geochemistry. Precambrian Research, v. 56, p. 97-111. 1992.

VANDERHAEGHE,O.;LEDRU,P:;THIÉBLEMONT,D;;EGAL, E.; COCHERIE, A.; TEGVEY, M.; MILÉSI, J. P. Contrasting mechanism of crustal growth: geodynamic evolution of the paleoproterozoic granite-greenstone belts of French Guiana. Precambrian Research, v. 92, p. 165-195, 1998.

VEIGA, A. T. C.; BRAIT FILHO, L.; OLIVEIRA, C. A. C. de. Geologia da Província Aurífera de cassiporé - Amapá. In: SIMPÓSIODEGEOLOGIADAAMAZÔNIA, 2., 1985. Belém. Anais. . Belém: SBG. 1993. p. 135-146.

VLETTER, D. R. DE; ALEVA, G J. J.; KROONENBERG S. B. Research into the Precambrian of Suriname. In: WONG, TH. E.; VLETTER, D. R. DE; KROOK, L.; ZNNEVELDT, J. I. S.; LOON, A. J. VAN. The history of earth sciences in Suriname. Amsterdam: Royal Netherlands Academy of applied Geoscience TNG, p. 15-64. 